\title{
THE FUTURE OF WORK IN THE VISEGRAD GROUP OF COUNTRIES ${ }^{1}$
}

\author{
MARK KEESE \\ Organisation for Economic Cooperation and Development, Paris, France \\ Email: mark.keese@oecd.org
}

\begin{abstract}
A number of megatrends are hitting the world of work at the same time. These include the digital revolution, globalisation and rapid population ageing, which are all having a profound impact on the types of jobs that are being created and how and where they are performed. This paper examines the challenges confronting the Visegrad Group of countries and the broad policy responses that will be required. It looks at the risk of job automation, how the structure of employment is changing by skill level and the rise of the gig economy. These changes will require a combination of policy responses in the areas of employment regulation, measures to facilitate labour mobility and lifelong learning, social protection and social dialogue. In many cases, this will not require a complete paradigm shift in policies but an adaptation and strengthening of existing polices.
\end{abstract}

Keywords: ageing, automation, skills, unions, post transition economies, labor policy

JEL-Codes: J11, J21, J24, J58, O33, P23

This paper represents the views of the author only and does not necessarily represent those of the OECD or its Member Countries. For their helpful comments, the author would like to thank the two referees of the paper, Stijn Broeke from the OECD, and participants at the conference on "Innovation, Integration and Mobility: The perspectives of sustainable employment in Europe", Corvinus University, Székesfehérvár, Hungary, 28-29 March 2018. 


\section{INTRODUCTION}

Across OECD countries, the world of work is continually changing but a number of megatrends, including technological change, globalisation and population ageing, may be combining to speed up and increase the magnitude of these changes. The Visegrad countries - the Czech Republic, Hungary, Poland and the Slovak Republic - are no exception in experiencing these megatrends but have also gone through a transition from centrally-planned to market-based economies. Has this transition left the labour markets in these countries more or less resilient in the face of these megatrends?

While it is difficult to answer this question definitively, some tentative conclusions are drawn in this paper. The methodology used is largely based on a comparative study of the situation facing Visegrad countries relative to other OECD countries. The paper begins by examining whether the global megatrends facing the Visegrad countries are different in magnitude than in other countries (Section 2). It then looks at how labour markets are changing as a result of these megatrends (Section 3). The adequacy of employment, social protection and skill development policies in the Visegrad countries to cope with these changes is discussed in Section 4. The paper concludes with some broad implications for policy responses in these countries to promote greater labour market resilience in the face of the structural changes that they are experiencing.

\section{THE MEGATRENDS SHAPING THE FUTURE OF WORK}

Several "megatrends" are sweeping across all OECD countries and are changing the nature of work - they affect what kind of work is done, who carries it out, and where and how it is carried out. These are: digitalisation, globalisation and demographic change. However, the speed and depth of these trends vary across countries with some notable differences both between the Visegrad countries and as compared with other OECD countries. Other factors such as climate change mitigation policies and changing consumer tastes and work preferences may also be amplifying the impact of these trends on the labour market.

\subsection{Technological progress}

Technological advances have been a continuous feature of all OECD economies and have led to huge gains in labour productivity since the first industrial revolution. However, recent advances in digital technologies, especially in Artificial Intelligence (AI), have increased the range of job tasks that can be potentially 
automated. Previously routine manual tasks were most at risk of being automated but this risk has spread to routine cognitive tasks and increasingly to even less routine job demands such as those involving problem-solving skills. The use of robots has been the most visible sign of job automation and there has been an acceleration over recent years in the global supply of industrial robots (Figure 1A). However, this trend has been far from uniform and the number of installed industrial robots per manufacturing employee varies considerably across countries (Figure 1B). Reflecting their relatively low labour costs, fewer robots are used in the Visegrad countries compared with countries such as Germany, Japan, Korea and the United States. Thus, there may be an elevated risk of a further loss in manufacturing jobs in these countries, especially in Hungary and Poland, as they catch up with other OECD countries in the adoption of robots. Moreover, recent developments in robotics and $3 \mathrm{D}$ printing may allow firms in those economies
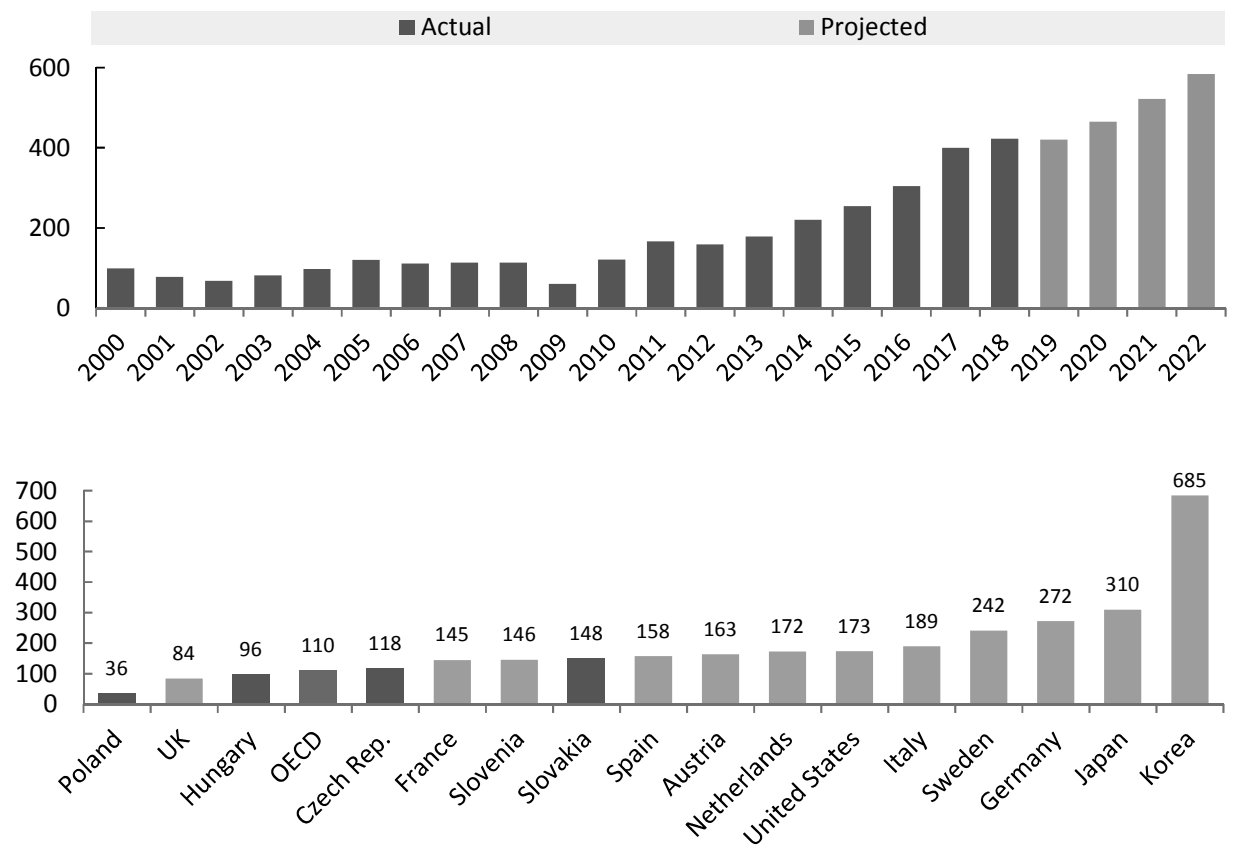

Figure 1. The robots are coming

Panel A. Estimated annual worldwide supply of industrial robots

Panel B. Installed industrial robots per 10,000 employees in manufacturing, 2017

Note: thousands of units in Panel A. The OECD average in Panel B is the median of all OECD countries, excluding Luxembourg

Sources: International Federation of Robotics $(2016 ; 2017 ; 2019)$ and OECD National Accounts for data on employees. 
that were previously outsourcing to the Visegrad economies to re-locate production back in their own country in more fully automated factories.

Technological advances are affecting labour markets in many other ways as well. For example, the internet facilitates new and more efficient ways of matching the demand for and supply of labour through online platforms. They can also facilitate changes in work organisation such as the greater use of teamwork and collaboration both within and across workplaces. While these developments can bring many positive benefits in terms of reducing reliance on dull, dirty and dangerous jobs and open up new job opportunities, they have raised concerns about the risk of job loss from automation and greater skills mismatch.

\subsection{Globalisation}

Changes in the labour market are also occurring because of increased international competition and trade. The production of goods and services within national economies has become less dependent on local demand and increasingly linked to foreign demand and international supply chains. This change over the past two decades has been particularly pronounced in the Visegrad countries (Figure 2), partly because of the opening up of their economies to international trade following their transition from centrally-planned to market-based economies. Trade as a share of GDP was higher in 2018 in both Hungary and Slovakia than in other small open economies such as the Netherlands and Slovenia. The rapid fall in the cost of communication and transportation has not only promoted the integra-

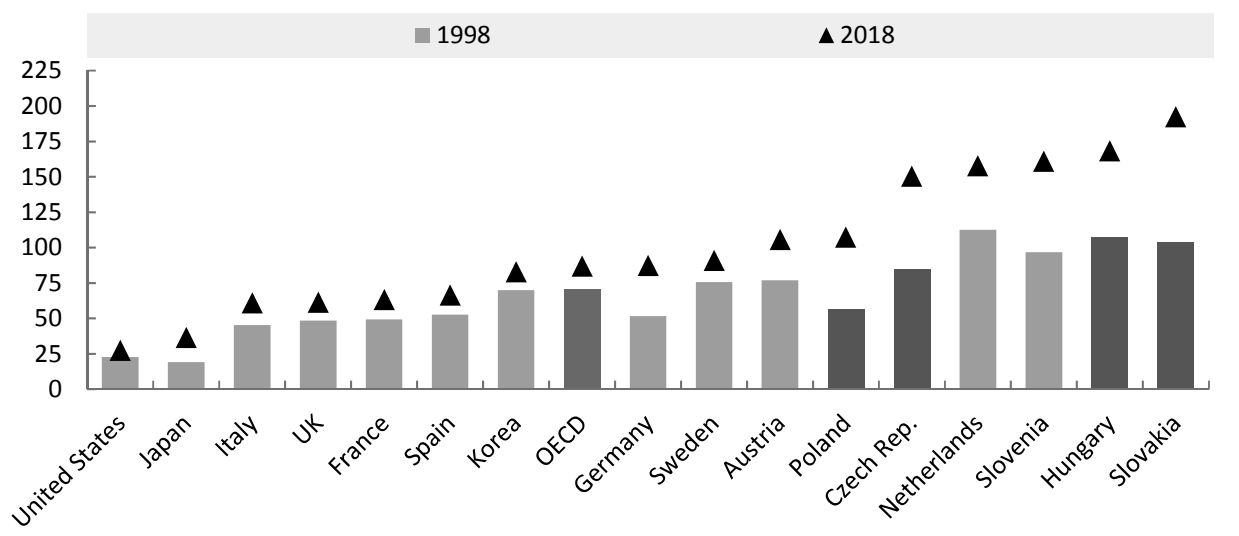

Figure 2. The world economy has become more integrated. Exports plus imports as a percentage of GDP

Note: the data for the OECD represent the median of all OECD countries.

Source: author's calculations based on OECD National Accounts data. 
tion of goods and services markets but has also facilitated an accelerated pace of technological dissemination. Growing international competition has itself also spurred companies to adopt new technologies and methods of production.

These developments have resulted in considerable outsourcing of production and services from high-labour-cost countries to lower cost ones, which have benefited the Visegrad countries in the past in terms of job creation. However, this process may be unwinding as labour costs rise in these countries and new technologies allow companies to "reshore" production that was previously outsourced. Éltető (2019) suggests that this may be a significant risk for Hungary and the other Visegrad countries.

\subsection{Demographic change}

Another challenge facing the Visegrad countries along with other OECD countries concerns rapid population ageing, which is putting pressure on future increases in prosperity and the sustainability of public finances. Currently, the proportion of the elderly population (aged 65 and over) relative to the number of the population of prime working-age (aged 20-64) is rather low in the Visegrad countries (Figure 3A). However, this will change over the next few decades. By 2050, the old-age dependency ratio is projected to be higher in these countries than on average in OECD countries, although still much lower than in some countries such as Italy, Spain, Korea and Japan.

These demographic changes will lead to important reallocations of labour and resources across sectors and occupations as demand shifts from durable goods (such as cars) towards services (such as health care). They will also result in a drag on economic growth as the labour force grows more slowly or even contracts. A key policy response will be to encourage later retirement and longer working lives. This is particularly important for the Visegrad countries where the employment rate for people aged 55 to 64 is quite low compared with many other OECD countries, especially in Poland (Figure 3B). In addition to pension reform, adult learning opportunities will need to be strengthened to ensure that workers are able to keep their skills up to date and acquire new ones throughout longer working careers involving more frequent job changes. This will also help to improve productivity as another important way to offset the drag on economic growth from slowing labour force growth. 

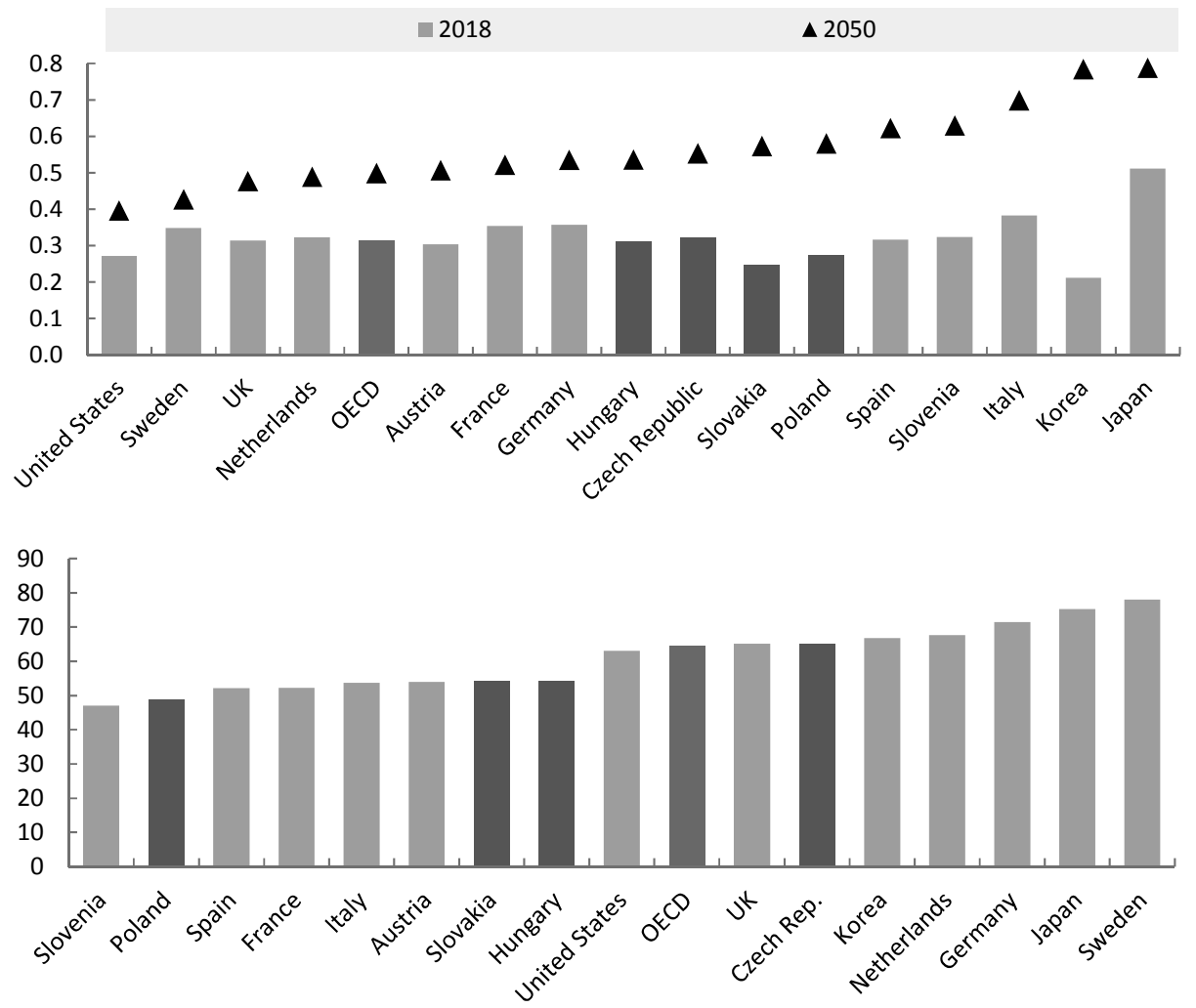

Figure 3. Populations are ageing rapidly

Panel A. Old-age dependency ratio (ratio of population aged 65+ to population aged 20-64)

Panel B. Employment rate of people aged 55-64 (\%), 2018

Note: the data for the OECD represent the median of all OECD countries.

Source: Panel A: OECD Database of Population and Labour Force Projections (unpublished); Panel B: OECD.Stat

\section{A CHANGING WORLD OF WORK}

Untangling the effects of these megatrends on labour markets in the Visegrad countries is difficult, not least because they are contemporaneous events but also because of the impact of other factors such as policy action to mitigate climate change and changes in consumer tastes and work preferences. In what follows, therefore, the focus is on key outcomes, regardless of which of the mega-trends is actually driving them. An international perspective is provided to gauge the magnitude of these changes relative to other OECD countries. More specifically, the 
implications of the mega-trends are analysed in terms of their impact on: (i) the risk of job loss; (ii) the skills that workers require; and (iii) new forms of work.

\subsection{The risk of job loss}

Of all the mega-trends, the digital revolution has been the focus of most concern because of the potential for large employment losses as a result of automation. While the job losses of major technological innovations in the past (e.g. the steam engine, electricity and the assembly line) have proven to be short-lived (Mokyr et al. 2015; OECD 2015a), there is no guarantee that this will continue to be the case in the future. Indeed, it has been argued that the "Second Machine Age" (Brynjolfsson - McAfee 2014), also dubbed the "Fourth Industrial Revolution" (Schwab 2016), is leading to greater possibilities for substitution of capital for labour for a far broader range of jobs than in the past, including those than previously were considered as requiring uniquely human abilities. Some have painted a particularly gloomy picture and believe that $47 \%$ of all persons employed in the US are currently working in jobs that could be performed by computers and algorithms within the next 10 to 20 years (Frey - Osborne 2013). Similar estimates for EU countries suggest that the share of jobs susceptible to automation ranges between $45 \%$ to more than $60 \%$, with the Visegrad countries at the upper end of the range (Bowles 2014).

However, more recent estimates by the OECD (Nedelkoska - Quintini 2018) suggest that the risk of automation is much lower once account is taken of: $i$ ) the range of tasks that are performed within each occupation; and ii) the significant differences in these tasks between workers in the same occupation. According to these estimates, only $14 \%$ of jobs faced a high risk of automation across the 28 OECD included in the study (Figure 4). This proportion is somewhat higher in the Visegrad countries, ranging from slightly higher at $15 \%$ in the Czech Republic to substantially higher at $34 \%$ in Slovakia. The estimate for Poland is also relatively high at $20 \%$.

In addition, substantial change in the way jobs are performed (i.e. jobs where $50-70 \%$ of the tasks performed could be automated) could affect a further $31 \%$ of jobs in those Visegrad countries for which data was available - a similar proportion as for the OECD average of $32 \%$. Altogether, between 47 and $64 \%$ of jobs in the Visegrad countries face automation or substantial change in the way they are performed, compared with the OECD average of $45 \%$. Estimates of job automation for Hungary are not available, as it did not participate in the OECD's (PIAAC) Survey of Adult Skills, which is the data source for the estimates for the other countries. Nevertheless, given that the occupational structure of em- 


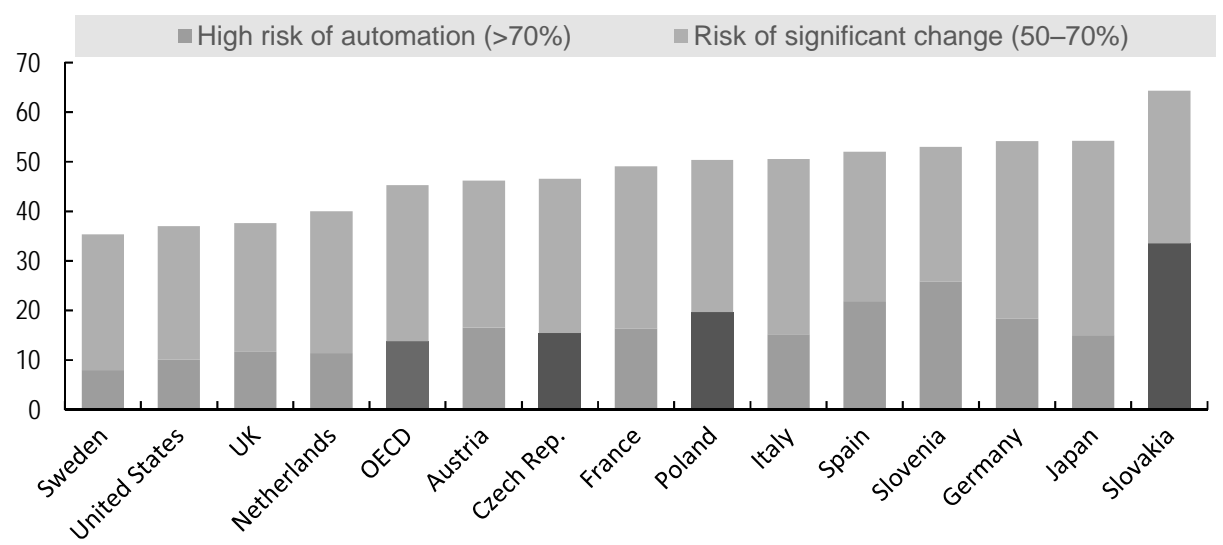

Figure 4. Only a minority of jobs have a high risk of automation in the near future.

Percent of all jobs by risk of automation

Note: A job is considered to have a high risk of automation if more than $70 \%$ of its tasks could be potentially automated. A job is considered to be at risk of significant change if between $50 \%$ and $70 \%$ of its tasks could be potentially automated. The data refer to the situation in 2011-2012 or 2014-2015 depending on the country concerned. The data for the OECD represent a weighted average of the OED countries in the OECD's Survey of Adult Skills (PIAAC).

Source: OECD calculations based on data from the OECD's Survey of Adult Skills (PIAAC), see Nedelkoska and Quintini (2018).

ployment in Hungary is closer to Slovakia than the Czech Republic or Poland, it is likely that a relatively high proportion of jobs in Hungary are also susceptible to automation.

Makó et al. (2018) reach similar conclusions that the risk of job automation is higher in the Visegrad countries than in many other EU countries. Based on the European Working Conditions Survey, they estimate that between 29 to 33\% of jobs in 2015 in the Visegrad countries involve predominantly routine tasks that could be automated, well above the EU27 average of $24 \%$. Hungary is at the upper end of the range. Estimates by McKinsey also find that the proportion of jobs that are potentially automatable is higher in the Czech Republic, Hungary and Poland than the EU average (Fine et al. 2018).

How should these OECD estimates of automation be interpreted, especially the finding that a third of current jobs in Slovakia could be potentially automated? It is important to note that these estimates cannot be simply equated with the actual or expected net employment losses arising from technological change. This will depend on the speed of adoption of new technologies, which can be quite slow, but also the relative costs of replacing human labour with machines. Labour costs are substantially lower in the Visegrad countries than in 
some of their neighbouring countries such as Austria and Germany and so employers may face less pressure to automate their production processes. Perhaps even more importantly, new jobs will also be created as a result of technological change and rising prosperity generated by the resulting boost to productivity. So, the net impact on employment will be lower than what these estimates of job loss from automation suggest.

Nevertheless, it is clear that a considerable number of jobs are potentially at risk of automation in the Visegrad countries, and, therefore, measures to promote labour mobility from old jobs to new ones will need to be reinforced. Special attention may be needed for those groups who are most likely to be affected by automation. This concerns low-skilled workers, women, and young and older workers relative to prime-age workers (Nedelkoska - Quintini 2018; OECD 2018b). The provision of good access to opportunities for re-skilling will be important not just for workers who lose their jobs but also for many incumbent workers who will see the skill requirements of their jobs change considerably.

\subsection{The skills that workers require}

As a result of digitalisation, but also driven by increased international trade and population ageing, there has already been considerable change in the skill profile of jobs over the past couple of decades. New technologies tend to be skilled biased, which means that their introduction increases the demand for high-skilled labour and reduces the demand for low-skilled labour. These technologies as well as offshoring have also been twisting demand away from jobs that mainly involve routine tasks whether cognitive or manual towards jobs that involve mainly nonroutine tasks. Consequently, many of the more economically advanced OECD countries have been experiencing a polarisation in the skill composition of jobs (Figure 5). There has been considerable growth in the employment share of highskilled occupations, some growth in non-routine low-skilled occupations associated with increased demand for personal care services, and a strong decline in the share of occupations that typically require only mid-level skills.

This pattern of polarisation has also occurred in the Visegrad countries, but with notable differences across them. The Czech Republic has followed more of a pattern of simple skills upgrading, and there has been a less pronounced increase in the share of high-skilled jobs in Hungary and Slovakia. With the exception of Poland, the fall in the share of middle-skilled jobs has also been less pronounced in the Visegrad countries than in some other OECD countries. This may reflect that the demand for middle skilled workers has been propped up by the location of production facilities in these countries by multinationals seeking cheaper labour but which may also be holding back demand for high-skilled workers. 


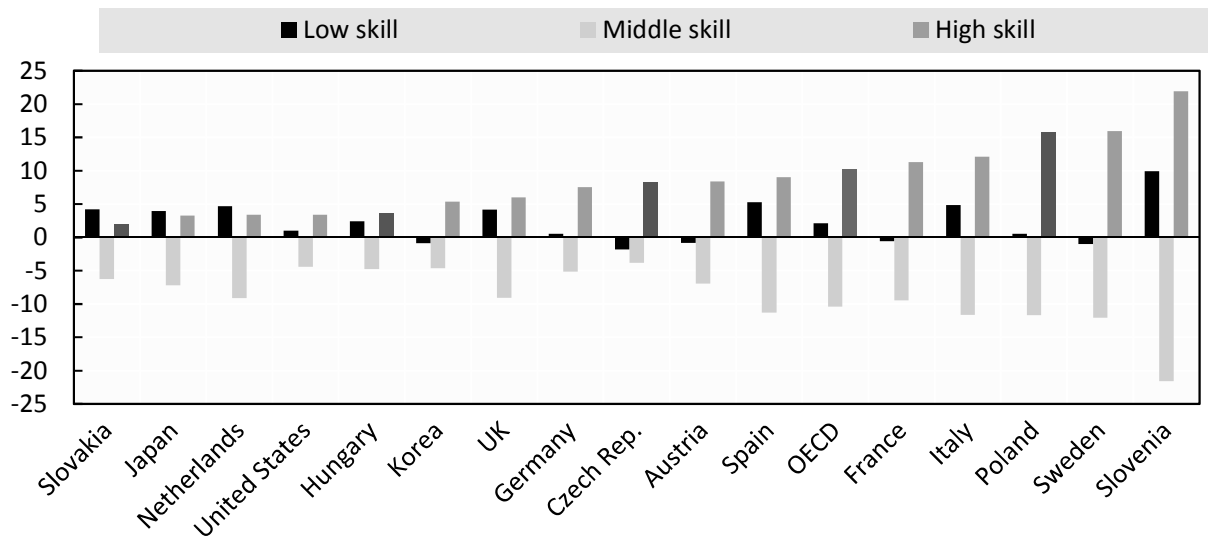

Figure 5. The disappearing middle: jobs by skill level. Percentage point change in share of total employment, 1998 to 2018

Note: High-skilled jobs correspond to ISCO-88 major groups 1, 2, and 3; Middle-skilled jobs correspond to major groups 4, 6, 7 and 8; and low-skilled jobs correspond to major groups 5 and 9. The OECD average is a simple unweighted average of selected OECD countries.

Source: Update of OECD (2017a: Chapter 3), based on data from the European and national labour force surveys.

In Poland, the steep fall in middle-skill jobs probably reflects the decline in the agricultural sector as a major source of employment. Looking to the future, the Visegrad countries may face a particular challenge if demand slumps further for middle-skilled workers who may not only see their jobs disappearing but also a stagnation in their wages relative to more skilled workers.

\subsection{New forms of work}

The interaction of technological progress with changing preferences is generating unprecedented opportunities for work to be carried out more flexibly. Of particular note has been the rise of the platform economy. For employers, this has provided access to a much larger pool of skills and experience at a fraction of the cost of hiring workers on traditional contracts (OECD 2016). The platform economy presents advantages for workers as well, since it allows them to choose both where and when they work - which can be particularly useful for single parents, students, disabled people and seniors (OECD 2016). However, much work in the platform economy involves small tasks carried out irregularly (see Pesole et al. 2018, for the European evidence on platform work). Platform workers may therefore have multiple jobs and work long or variable hours under high stress. In 
addition, such work frequently has no social security coverage, can be terminated at will, and may be poorly remunerated due to a high level of competition.

Platform work consists of work that is obtained through websites or mobile apps. It can be conducted online (e.g. a computer coder) or in person in a local market (e.g. an Uber driver). While there is much talk about the rise of the platform economy, reliable and internationally comparable data are currently not available. Nevertheless, some partial indicators are available. The Online Labour Index captures global demand for online platform work in English and suggests that there has been considerable growth in recent years, albeit with some slowdown since early 2018 (Figure 6A). However, most existing estimates suggest that the overall level of such work remains low. In the United States, for example, which has been at the forefront of the development of platform work, the share of workers involved accounted for 1\% of total employment in May 2017 (U.S. Bureau of Labor Statistics 2018; see also Katz - Krueger 2016). A survey of internet users in $14 \mathrm{EU}$ countries also suggests that the proportion of the adult population (aged 15 to 74) that are platform workers is quite small (Pesole et al. 2018). The proportion is particularly low in Hungary and Slovakia, the two Visegrad countries in the survey, with fewer than $1.5 \%$ of adults obtaining more than $50 \%$ of their income from platform work compared with over $4 \%$ in the United Kingdom.

Another partial indicator that is available for all EU countries from the European labour force survey is the proportion of workers who are own-account workers (i.e. self-employed without employees) in either their first or second jobs. While this will also capture own-account workers who are performing their jobs off line, it provides a useful indicator of a more general form of non-standard work beyond just platform work. Between 2000 and 2018, the incidence of own-account working rose in many but not all EU countries and so was broadly stable for the EU as a whole (Figure 6B). The picture was also mixed among the Visegrad countries with some increase in the Czech Republic and Slovakia but with large falls recorded in Hungary and Poland, possibly linked to the decline of small-scale agriculture. Thus, it would seem that the incidence of platform work and other forms of non-standard employment such as own-account working remain modest in magnitude for the Visegrad countries. 

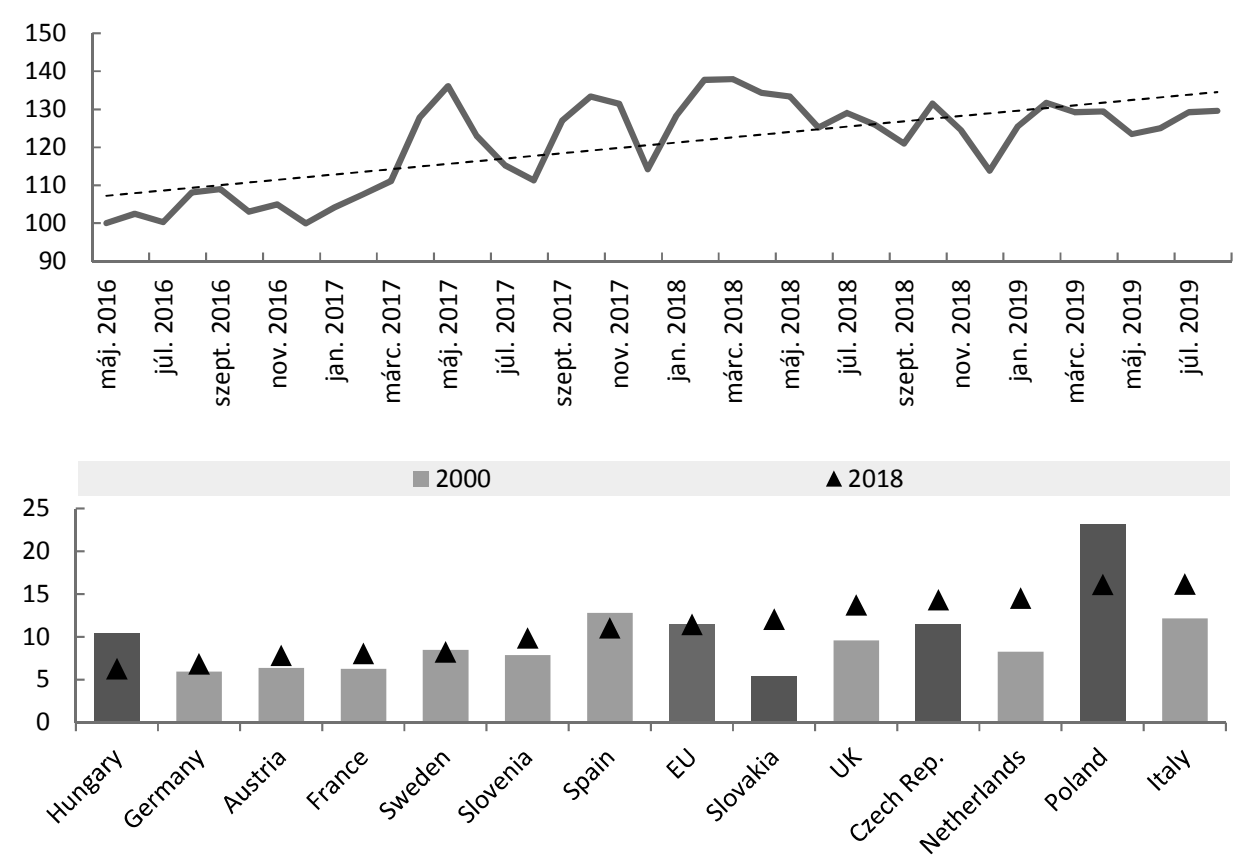

Figure 6. New forms of work are emerging

Panel A. Online gig work is growing rapidly from a small base. Monthly averages of daily data for global new vacancies in English for online gig work, May 2016=100

Panel B. Own-account working has increased in some but not all countries. Own-account workers in first or second job as a \% of all workers, 2000 and 2018

Note: The online labour index in Panel A corresponds to all vacancies posted in English for online gig work. Own-account workers in Panel B are self-employed workers without any employees in either their first or second jobs.

Source: Panel A, Oxford Internet Institute's Online Labour Index, see Kässi and Lehdonvirta (2019); Panel B, author's calculations based on the results of the European Labour Force Survey.

\section{POLICY RESPONSES: PARADIGM SHIFT OR UPDATE?}

In the face of these changes in the labour market, is there a need for a paradigm shift in labour market and social policies and institutions or just some adaptation and updating? And is more extensive policy reform required in the Visegrad countries? These questions are assessed for five key policy areas which will have an important influence on how well individual workers and countries are able to weather the changes occurring in the labour market with the least disruption possible, while maximising the potential benefits that will also arise. These are: 
social protection; employment regulation; measures to facilitate labour mobility; skills development; and social dialogue.

\subsection{Social protection}

It has been suggested that the sustainability of social security systems is at risk because of both falling contributions and rising expenditures. Contributions may shrink because of the growth in non-standard forms of work not subject to social security contributions, outsourcing of work to other countries and the slowdown in labour force growth linked to population ageing. At the same time, social expenditures could rise steeply because of rapidly growing numbers of pensioners as populations age and larger numbers of unemployed workers are displaced from their jobs by technological change. These concerns have prompted various proposals to introduce a universal basic income that would guarantee a minimum income for everyone irrespective of whether employed or not or type of working arrangement. However, the design of these types of schemes raise many difficult issues including their cost and which groups would benefit or lose out from their introduction relative to current arrangements (OECD 2017b). Moreover, this would appear to be a radical response when it is still far from clear how extensive job losses may be and when platform work remains rather rare even if growing quickly.

What is clear is that if nothing is done, existing holes in the social safety net may become even larger as non-standard forms become more prevalent. Access to various social security benefits for the self-employed provides one indication of where these holes exist for one important form of non-standard employment (Table 1). In only relatively few EU countries are all types of social security benefits available to employees also available to the self-employed. This is the case in Hungary but not in the other Visegrad countries. For example, the self-employed Czech Republic and Poland may choose to opt into the schemes for parental and sickness benefits, and in Slovakia they do not have access to the scheme for occupational accidents and injuries that covers employees. At the same time, these gaps in social security coverage do not appear to be more consequential in these countries than in many other EU countries.

Nevertheless, steps should be taken to close these gaps by defining more clearly the status of self-employed workers and by ensuring that "vulnerable" self-employed with little bargaining power have access to standard social security benefits (see OECD 2019a: Chapter 4). For instance, under Denmark's new unemployment benefit arrangements all income sources will be treated equivalently (equal rights for self-employed, non-standard workers, on demand worker and standard workers), which will allow people to combine self-employment and employment 
Table 1. Benefit rules for the self-employed are different from those of standard workers

\begin{tabular}{|c|c|c|c|c|c|c|}
\hline & Old-age & Invalidity & $\begin{array}{l}\text { Parental } \\
\text { benefits }\end{array}$ & $\begin{array}{l}\text { Sickness } \\
\text { benefits }\end{array}$ & $\begin{array}{l}\text { Occupational } \\
\text { accidents and } \\
\text { injuries }\end{array}$ & $\begin{array}{l}\text { Unemployment } \\
\text { benefits }\end{array}$ \\
\hline Czech Rep. & Full & Full & $\begin{array}{l}\text { Voluntary } \\
\text { opt-in }\end{array}$ & $\begin{array}{l}\text { Voluntary } \\
\text { opt-in }\end{array}$ & Full & Full \\
\hline Hungary & Full & Full & Full & Full & Full & Full \\
\hline Poland & Full & Full & $\begin{array}{l}\text { Voluntary } \\
\text { opt-in }\end{array}$ & $\begin{array}{l}\text { Voluntary } \\
\text { opt-in }\end{array}$ & Full & Partial \\
\hline Slovakia & Full & Full & Full & Full & None & Full \\
\hline Austria & Full & Full & Full & Full & Full & $\begin{array}{l}\text { Voluntary } \\
\text { opt-in }\end{array}$ \\
\hline France & Full & Full & Partial & Partial & None & None \\
\hline Germany & Partial & Partial & Partial & Partial & $\begin{array}{l}\text { Voluntary } \\
\text { opt-in }\end{array}$ & None \\
\hline Italy & Full & Partial & Full & None & Full & None \\
\hline Netherlands & Partial & $\begin{array}{l}\text { Voluntary } \\
\text { opt-in }\end{array}$ & Partial & $\begin{array}{l}\text { Voluntary } \\
\text { opt-in }\end{array}$ & $\begin{array}{l}\text { Voluntary } \\
\text { opt-in }\end{array}$ & None \\
\hline Slovenia & Full & Full & Full & Partial & Full & Full \\
\hline Spain & Partial & Full & Full & Full & $\begin{array}{l}\text { Voluntary } \\
\text { opt-in }\end{array}$ & $\begin{array}{l}\text { Voluntary } \\
\text { opt-in }\end{array}$ \\
\hline Sweden & Full & Full & Full & Full & Full & Partial \\
\hline UK & Partial & Partial & Partial & Partial & None & Partial \\
\hline
\end{tabular}

Source: Pesole et al. (2018).

income, and makes it simpler for self-employed individuals to prove discontinuation of operations. To finance benefits, new types of workers will also need to be covered by the tax system. In France, since the introduction of the Finance Bill 2016, all platforms are required to provide an annual earnings statement to service providers in order to facilitate their tax returns. In Estonia, the tax authorities are working together with platform operators to develop a system whereby tax is withheld directly via the platform to facilitate income tax collection. There may also be scope to encourage platforms to put in place their own mechanisms to improve worker protection. For example, the freelancer platform Upwork offers a number of services including unemployment and health insurance.

\subsection{Employment regulation}

Social protection not only implies some form of income guarantee if out of work but also protection while in work from arbitrary dismissal, wage exploitation, and poor working conditions. Therefore, a whole raft of employment regulations have been developed in all OECD countries to provide this protection to work- 
ers in standard forms of employment. However, concerns have been raised that these employment regulations are becoming increasingly outdated in the face of the rising numbers of workers in non-standard forms of employment, such as platform workers.

Again, it is not clear whether wholesale reform of employment regulations is needed or whether it is a matter of partial reform and better enforcement of existing regulations. For example, one issue is to guarantee that platform workers receive fair wages. There are minimum wage arrangements in most countries, including for piece work and home work. It may be the case that steps could be taken to apply these measures more explicitly to platform work. With respect to employment protection legislation governing hiring and firing of workers, it may also be a matter of defining more clearly the employment status of a worker to prevent misclassification of employees as independent contractors. In some countries, this may also require shifting the burden of proof of employment status from the individual worker to the contracting company/employer. Finally, it may also be a case of reducing incentives to substitute non-standard form of work for standard ones. For example, in the Netherlands, there has been a considerable rise in the incidence of non-standard forms of employment but this has been largely driven by a large gap in the strictness of employment protection legislation for permanent workers versus temporary workers and in the tax and social security treatment of employees versus independent contractors (OECD 2018c).

\subsection{Measures to facilitate labour mobility}

Well-functioning social safety nets can ensure that workers who lose their jobs because of digitalisation or globalisation have adequate income support while out of work. However, this needs to be accompanied by help in finding another job. More specifically, countries need to have in place an effective activation framework which: (i) motivates jobseekers to actively pursue employment; (ii) improves their employability; and (iii) expands the set of opportunities for them to be placed and retained in appropriate jobs (OECD, 2015c). Strong activation policies can help countries mitigate some of the inevitable adjustment costs of moving towards more globalised and technologically advanced economies. One indicator of the resources devoted to this support can be constructed by expressing total expenditure on Active Labour Market Programmes (ALMPs) per unemployed person as a per cent of GDP per capita (Figure 7). In the Visegrad countries, relative to their GDP per capita, expenditure on ALMPs per unemployed person has risen considerably since 2006 with the exception of Slovakia. Nevertheless, with the exception of Hungary, this ratio remains low in these countries relative to countries such as Austria, Germany and Sweden. 


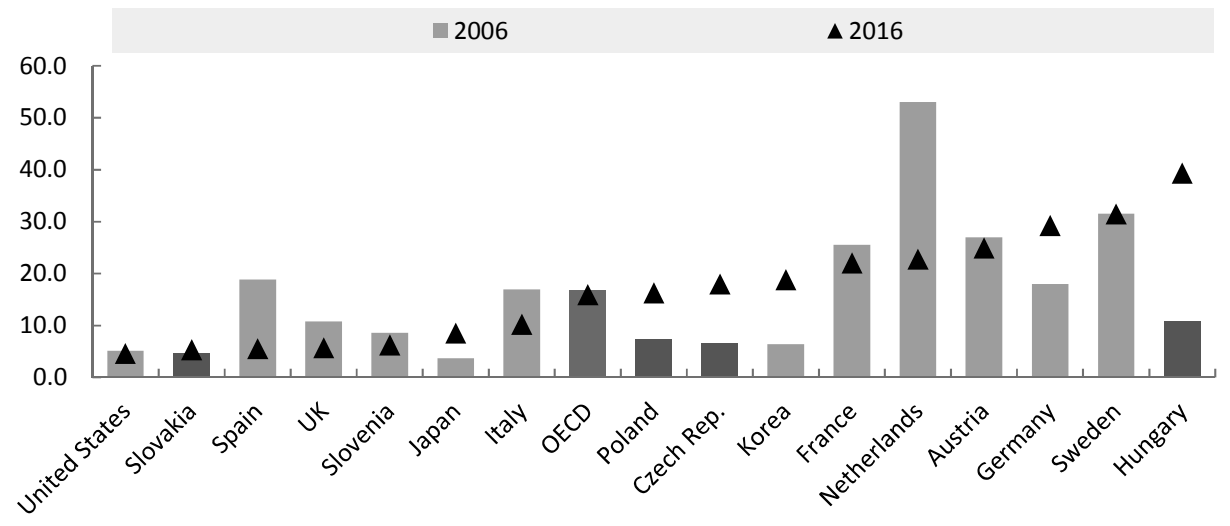

Figure 7. Resources for helping the unemployed have risen. Spending on ALMPs per unemployed person as a percentage of GDP per capita

Note: ALMPs refer to Active Labour Market Programmes. The data for 2016 refer to 2015 for France, Italy and Spain. The data for the OECD represent a simple average of all OECD countries.

Source: Author's calculations based on data on ALMP expenditure, total unemployment and GDP per capita from OECD.Stat.

\subsection{Skill development}

Changing skill needs as a result of new technologies and globalisation raise considerable challenges for all countries to ensure that the skills workers possess match those required by employers. There are already signs of emerging skills imbalances across EU countries (Figure 8). In general, there are skill shortages in those areas where demand has been strongest such as for reasoning and verbal abilities, knowledge of computers and electronics, or complex problem-solving skills. Similarly, skill surpluses have emerged in areas where demand has been weaker such as abilities requiring physical strength or knowledge of manufacturing and production. This pattern is broadly similar in the Visegrad countries although with some notable exceptions. For example, Poland has a surplus of skills requiring a knowledge of health services. Whereas, along with the Czech Republic, it has a shortage in skills requiring a knowledge of manufacturing and production. In contrast to EU countries on average, Hungary does not appear to be facing a shortage in skills requiring a knowledge of computers and electronics or in complex problem solving skills.

To tackle these skill imbalances, governments will need to ensure that young people enter the labour market with the right type of skills to navigate successfully an ever-changing, technology-rich work environment. But, even more criti- 


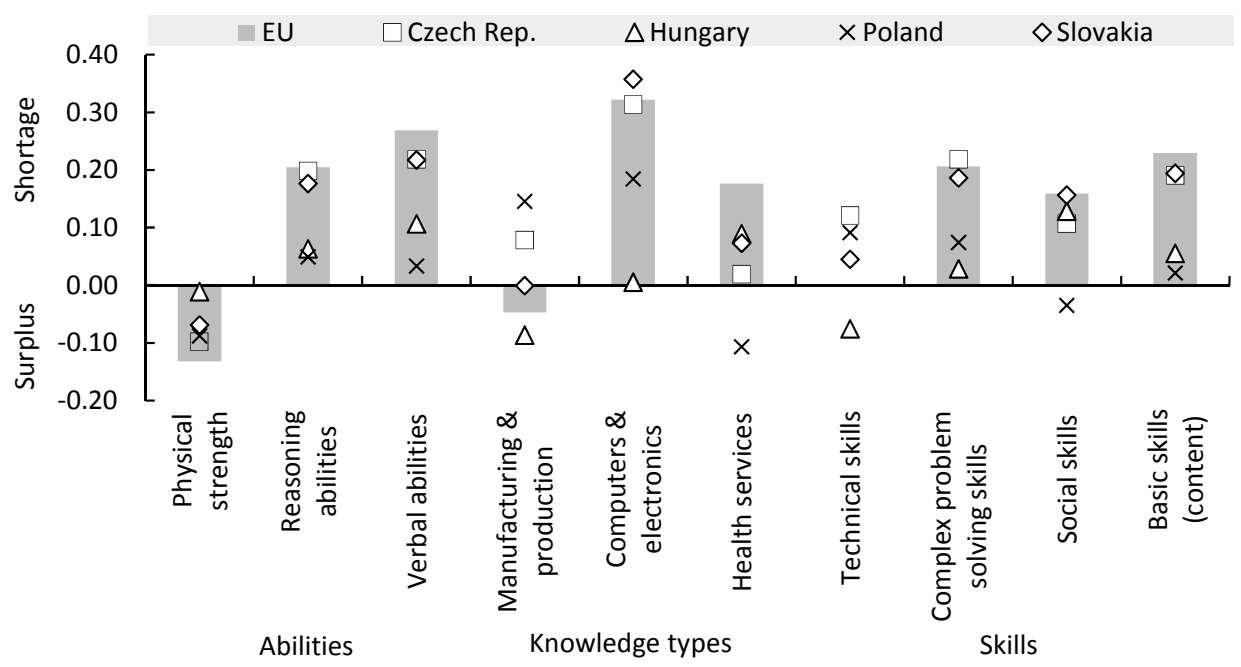

Figure 8. Emerging skill gaps. Index of the intensity of skill shortages or surpluses, 2015

Note: The EU average refers to a simple average of all EU countries.

Source: OECD Skills for Jobs Indicators, OECD.Stat.

cally, better opportunities will also be needed for workers who are already in the workforce to update their skills and learn new ones. In the context of rapid population ageing, these workers will be facing longer worker lives and a greater risk of their skills becoming obsolete because of technological change.

Currently, investments in adult learning vary considerably across countries but also within countries among workers by skill level (Figure 9). Of particular concern is the low rates of participation in training in most countries for workers with few educational qualifications. The picture for the Visegrad countries is quite mixed, with a relatively high rate of training on average in Slovakia relative to the EU average but still well below the rates in Austria, the Netherlands and Sweden. Participation in training is particularly low in Poland. The gap in training participation between the low-skilled and the high-skilled is also large in the Visegrad countries, with the partial exception of Hungary. Thus, measures will need to be considered that encourage both a general rise in training participation but which also promote greater inclusiveness with respect to access to training across different groups of workers (for examples of policies to achieve this, see OECD 2019b). Efforts should also be targeted at small- and medium-sized enterprises, which tend to engage in much less training than larger enterprises. 


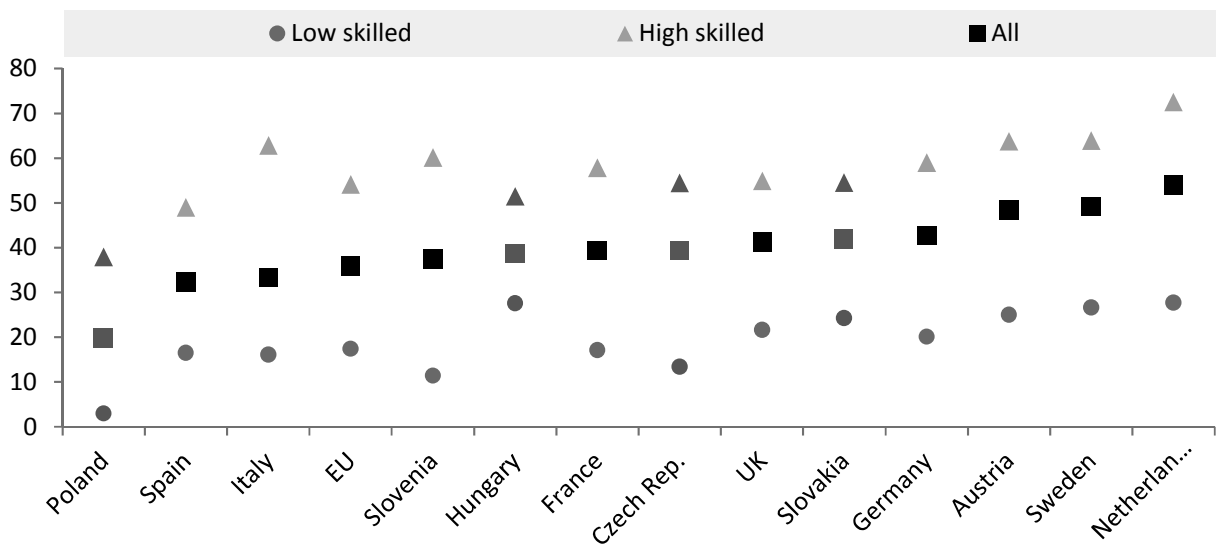

Figure 9. Turning lifelong learning into a reality. Participation rate in job-related non-formal training by educational level for adults aged 25-64, $2016(\%)$

Note: $\mathrm{EU}$ is the weighted average of all $\mathrm{EU}$ countries.

Source: European Adult Education Survey (2016), as extracted from the Eurostat database.

\subsection{Social dialogue}

Social dialogue can play a key role in facilitating the adoption of new technologies and changes in work organisation as well as in ensuring that the benefits of these changes are more widely shared. However, in nearly all OECD countries, there has been a long-term decline in trade union membership and in collective bargaining coverage. The decline in the proportion of workers who are trade union members has been particularly steep in the Visegrad countries to well below the OECD average (Figure 10). As in other countries, this trend decline has been driven by ongoing structural change. With the rise in new forms of employment, and platform work in particular, there is a risk of further erosion in the collective representation of workers in the Visegrad countries.

These developments are not inevitable. First, governments can minimise impediments to worker organisation such as provisions in competition law that prevent collective bargaining by self-employed workers (for a more detailed discussion of this issue see Chapter 5, OECD, 2019a). For example, the Polish Parliament is considering a draft amendment to the Act on Trade Unions which will grant the right to establish and join trade unions to workers engaged under civil law contracts. Second, innovative forms of new social partnerships are emerging. For example, in the United States, the Freelancers Union promotes the interests of independent workers, including platform-based workers. Third, traditional trade union also have a role to play in helping workers in non-standard 

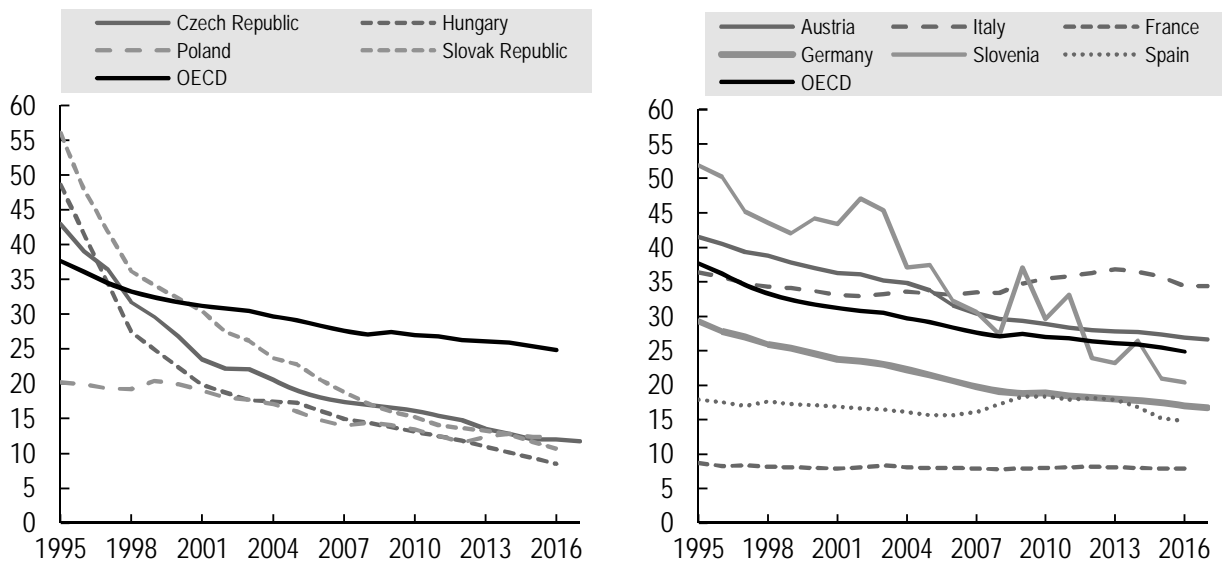

Figure 10. Formal representation of workers is in decline.

Active trade union members as a percent of all employees

Note: OECD is a simple average of all OECD countries.

Source: OECD.Stat.

forms of employment to organise. For example, in Germany, the largest metalworkers' union (IG Metall) has been behind the creation of FairCrowdWork Watch, a platform dedicated to improving digital workers' working conditions. Similarly, ver.di, the United Services Union, is providing legal and support services for crowd-workers.

\section{CONCLUSIONS}

As for other OECD countries, the labour markets in the Visegrad countries are being buffeted by a number of megatrends. In some areas, these "winds of change" are more intense than in many other OECD countries. For instance, they are small open economies and their exposure to world trade has grown substantially following their transition to market-based economies. Their populations are also ageing rapidly, although to a lesser extent than in some other European countries such as Austria and Germany and far less than in Japan. They are also lagging somewhat in the adoption of new technology as measured by the use of industrial robots.

While the challenges arising from these megatrends differ somewhat in their nature and intensity among the Visegrad countries, some common findings emerge. First, workers in these countries, especially in Slovakia, face a greater 
risk of automation than on average across OECD countries. Second, with the exception of Poland, the pattern of polarisation in the skill composition of jobs over the past 20 years has been less pronounced in the Visegrad countries than in several other OECD countries. If demand for middle skilled workers weakens in the future as has occurred in other countries, this could lead not only to a loss of jobs for this segment of workers but also stagnation in their wages relative to more skilled workers. Third, while platform work remains relatively uncommon in the Visegrad countries, there are signs that other forms of non-standard employment have increased or remain widespread, with the notable exception of Hungary.

In terms of policy responses to these challenges, the overall message is that reform rather than a paradigm shift is needed. First, steps should be taken to close gaps in the coverage of the social security system by defining more clearly the status of different forms of employment and in ensuring that workers in non-standard forms of employment have greater access to standard social security benefits. Second, existing provisions with respect to employment regulation should be better enforced such as by applying minimum piece rates to platform workers or again by more clearly defining employment status and shifting the burden of proof of status from the individual worker to the contracting company. Third, there needs to be adequate resources devoted to effective Active Labour Market Programmes (ALMPs) that help facilitate labour mobility. Over the past decade, there has been some increase in resources devoted to helping job seekers in most of the Visegrad countries but, with the exception of Hungary, to levels that remain modest in comparison with some other countries such as Austria, Germany and Sweden. Fourth, lifelong learning has to be turned into a reality. Participation in training in the Visegrad countries remains well below the rates in Austria, the Netherlands and Sweden, particularly in Poland. The gap in training participation between the low-skilled and the high-skilled is also large in these countries, with the partial exception of Hungary. Finally, social dialogue needs to be strengthened, particularly in the Visegrad countries where the representation of workers by unions has fallen substantially over the past 20 years. 


\section{REFERENCES}

Bowles, J. (2014): The Computerisation of European Jobs. http://bruegel.org/2014/07/thecomputerisation-of-european-jobs/, accessed 03/11/2019.

Brynjolfsson, E. - McAfee, A. (2016): The Second Machine Age: Work, Progress, and Prosperity in a Time of Brilliant Technologies. New York: W. W. Norton.

Éltetö, A. (2019): Effects of Industry 4.0 on Reshoring Investments - Hungarian Experiences. HAS Centre for Economic and Regional Studies Institute of World Economics Working Paper No. 251.

Fine, D. - Havas, A. - Hieronimus, S. - Jánoskuti, L. - Kadocsa, A. - Puskás, P. (2018): Transforming Our Jobs: Automation in Hungary. McKinsey \& Company. https://www.mckinsey.com/ / media/McKinsey/Locations/Europe\%20and\%20Middle\%20East/Hungary/Our\%20Insights/ Transforming\%20our\%20jobs\%20automation\%20in\%20Hungary/Automation-report-onHungary-EN-May24.ashx, accessed 03/11/2019.

Frey, C. B. - Osborne, M. (2013): The Future of Employment: How Susceptible Are Jobs to Computerisation? Oxford Martin Programme on Technology and Innovation Working Paper.

International Federation of Robotics (2016): World Robotics, 2016. Frankfurt am Main: International Federation of Robotics.

International Federation of Robotics (2017): World Robotics, 2017. Frankfurt am Main: International Federation of Robotics.

International Federation of Robotics (2019): World Robotics, 2019. Frankfurt am Main: International Federation of Robotics.

Kässi, O. - Hadley, M. - Lehdonvirta, V. (2019): Online Labour Index: Measuring the Online Gig Economy for Policy and Research. Dataset. https://doi.org/10.6084/m9.figshare.3761562, accessed 03/11/2019.

Katz, L. F. - Krueger, A. B. (2016): The Rise and Nature of Alternative Work Arrangements in the United States, 1995-2015. Harvard University Department of Economics Working Paper. http:// scholar.harvard.edu/files/lkatz/files/katz_krueger_cws_v8.pdf, accessed 03/11/2019.

Makó, C. - Illéssy, M. - Borbély, A. (2018): Automatizáció és kreativitás a munkavégzésben [Automation and Creativity at Work]. Educatio 27(2): 192-207.

Mokyr, J. - Vickers, C. - Ziebarth, N. L. (2015): The History of Technological Anxiety and the Future of Economic Growth: Is This Time Different? Journal of Economic Perspectives 29(3): $31-50$.

Nedelkoska, L. - Quintini, G. (2018): Automation, Skills Use and Training. OECD Social, Employment and Migration Working Papers No. 202.

OECD (2015): OECD Digital Economy Outlook 2015. Paris: OECD Publishing.

OECD (2016): New Markets and New Jobs, Background Report for the 2016 Ministerial Meeting on the Digital Economy. Paris: OECD Publishing.

OECD (2017a): OECD Employment Outlook 2017. Paris: OECD Publishing.

OECD (2017b): Basic Income as a Policy Option: Can It Add Up? OECD Policy Briefs on the Future of Work. Paris: OECD Publishing.

OECD (2018a): OECD Employment Outlook 2018. Paris: OECD Publishing.

OECD (2018b): Putting a Face Behind the Jobs at Risk of Automation. OECD Policy Briefs on the Future of Work. Paris: OECD Publishing.

OECD (2018c): OECD Economic Surveys: Netherlands 2018. Paris: OECD Publishing.

OECD (2019a): OECD Employment Outlook 2019: The Future of Work. Paris: OECD Publishing.

OECD (2019b): Getting Skills Right: Future-Ready Adult Learning Systems, Getting Skills Right. Paris: OECD Publishing. 
Pesole, A. - Urzí Brancati, M. C. - Fernández-Macías, E. - Biagi, F. - González Vázquez, I. (2018): Platform Workers in Europe. Luxembourg: Publications Office of the European Union.

Schwab, K. (2016): The Fourth Industrial Revolution. Geneva: World Economic Forum.

U.S. Bureau of Labor Statistics (2018): Electronically Mediated Work: New Questions in the Contingent Worker Supplement. Monthly Labor Review, September. Washington DC: U.S. Bureau of Labor Statistics.

Open Access. This is an open-access article distributed under the terms of the Creative Commons Attribution-NonCommercial 4.0 International License (https://creativecommons. org/licenses/by-nc/4.0/), which permits unrestricted use, distribution, and reproduction in any medium for non-commercial purposes, provided the original author and source are credited, a link to the CC License is provided, and changes - if any - are indicated. 